\title{
Öğrenci hemşirelerde stres yaratan durumlar ve baş etme yöntemleri
}

\author{
Mualla Yılmaz ${ }^{1}$, Zeliha Yaman1, Semra Erdoğan² \\ ${ }^{1}$ Mersin Üniversitesi, İçel Sağlık Yüksekokulu, Psikiyatri Hemşireliği Anabilim Dalı, Mersin \\ 2Mersin Üniversitesi, Tıp Fakültesi, Biyoistatistik ABD, Mersin
}

$\ddot{0} \mathrm{z}$

Amaç: Bu araştırma, hemşirelik bölümünde öğrenim gören öğrenci hemşirelerde stres yaratan durumlar ve baş etme yöntemlerinin belirlenmesi amacıyla tanımlayıcı olarak yapıldı. Yöntem: Bu araştırma bir Sağlık Yüksekokulu Hemşirelik Bölümü'nde öğrenim gören 531 öğrenciden gönüllülük ilkesi gereği araştırmaya katılmayı kabul eden 280 öğrenci ile yapılmıştır. Araştırma verileri "Öğrenci Hemşirelerde Stres Yaratan Durumlara İlișkin Bilgi Formu" ve "Stresle Başa Etme Tarzları Ölçeği" kullanılarak toplandı. Verilerin değerlendirilmesinde yüzdelik, ortalama, ortanca, Mann Whitney U ve Kruskall Wallis testleri kullanıldı. Bulgular: Çalışmaya katılan öğrenci hemşirelerin \%58,3'ü 20 yaş ve üzerinde olup yaş ortalaması $21,0 \pm 2,0$ 'dir. Öğrenci hemşirelerin klinik alandaki strese neden olan faktörleri incelendiğinde; \%50,7'si öğretim elemanlarının bakım planı konusundaki ısrarı/sıkıștırma davranışında bulunma, \%63,2'si hastaların öğrenci hemşireye güvenmemeleri, \%43,6'sı öğrencilerin klinik uygulamalarda hata yapma korkusu, \%44,6'sının sınav kaygısı nedeniyle stres yaşadıkları belirlendi. Ayrıca öğrenci hemşirelerin \%26,8'inin üniversitede sosyal etkinliklerin olmaması ve \%22,5'inin ise yakınlarının hemşireliğe yönelik olumsuz ön yargısından dolayı stres yaşadıkları belirlenmiştir. Öğrenci hemşirelerin stresle başa çıkma tarzları içerisinde en fazla kendine güvenli yaklaşım ve sosyal destek arama yöntemini kullandıkları saptandı. Sonuç: $\mathrm{Bu}$ araştırmada öğrenci hemşirelerin eğitim sürecinde, klinik ortamda ve öğrenci yakınlarının hemşireliğe yönelik olumsuz ön yargısından dolayı stres yaşadıkları belirlenmiştir. Öğrenci hemşirelerin bu stresleri tanımaları ve stresle bașetme becerileri kazanmasında hemşire akademisyenlerin görev ve sorumluluklarının olması gerekmektedir.

Anahtar Kelimeler: Stres, öğrenci, hemşirelik, stresle başa çıkma

Yazının geliş tarihi:13.01.2017

Yazının kabul tarihi:03.05.2017

Yazışma adresi: Doç.Dr. Mualla Yılmaz, Mersin Üniversitesi, İçel Sağlık Yüksekokulu, Psikiyatri Hemşireliği Anabilim Dalı, Çiftlikköy Kampüsü Mezitli/Mersin

Tel: 05359207263

E-posta: mualley69@gmail.com 


\title{
Stressful situation in nursing students and the methods of coping with stress
}

\begin{abstract}
Aim: This descriptive study is aimed to determine the stress causing factors of the students studying at nursing department and their coping methods. Method: The universe of the study consists of 531 students who have been studying at the Nursing Department of Mersin University School of Health and the sample consists of 280 students who accepted to participate in the study. "Knowledge Form is related to stressfull situations in Nursing Students" and "Stress-Coping Style Scale" were used for data collecting. In data analysis, percentage mean, median, $25-75 \%$ percentile, Mann Whitney $U$ and Kruskal-Wallis variants analysis test were used. Results: The mean age of the students participated to the study was $21,0 \pm 2,0$ years and $58,3 \%$ were 20 years and over. It was found out that the stress factors experienced by the students at clinical areas are as the followings 50,7\% lecturers' attitude/compression behavior on nursing care plan, $63,2 \%$ patients' being the sense of insecurity against nursing students, $43,6 \%$ fear of making mistakes in clinical practice, $\% 44,6$ exam anxiety. It was also determined that $26,8 \%$ of the student nurses experience stress because of the lack of social activities and $22,5 \%$ of them experience because of the negative prejudice of nursing students' relatives towards nursing. It was determined that among the ways of coping with stress, the student nurses use the Self-Confidence Approach and Social Support Search method the most. Conclusion: In this study, it was determined that the student nurses were experiencing stress in the educational process, in the clinical setting and negative prejudice of the students' relatives towards nursing. Student nurses recognize these stressors and nurse academicians must have responsibilities to be able to cope with stress.
\end{abstract}

Keywords: Stress, student, nursing, coping with stress

\section{Giriş}

Stres, modern toplum hastalığ olarak ifade edilen, günlük hayatımızın ayrılmaz bir parçası olan bir kavramdır.1,2 Çok eski çağlardan beri stres insanoğlunun yaşamında var olan bir durumdur. Eski çağlarda hayatta kalmak için yapılan mücadeleler sonucunda yaşanan stres ile günümüzde yaşadığımız stres arasında önemli fark yoktur. ${ }^{2}$

Stres, organizmanin bedensel ve ruhsal sinırlarının tehdit edilmesi, zorlanması ile ortaya çıkan, bireyin fiziksel ve ruhsal dengesini tehdit eden bir durum olarak tanımlanmaktadır. İnsanların hayatlarını geniş çaplı etkileyebilecek olaylar stres sebebi olabilirken, önemli hayat değişiklikleri, bireyin her zaman karşılaşabileceği günlük yaşam olayları da stres unsuru olabilmektedir. ${ }^{1}$

Stresle başa çıkma diğer bir deyişle stres yönetimi, temel olarak stres Mersin Univ Saglık Bilim Derg 2017;10(2) yaşantısının olumsuz sonuçlarını azaltmaya ya da yok etmeye yönelik çabalarla stresin etkisini olumlu düzeyde tutabilmek olarak tanımlanabileceği gibi bireyin kaynaklarını aşan ya da zorlayan çevreden ve içten gelen istek ve çatışmaları kontrol etmeye yönelik dinamik, bilişsel, duygusal ve davranışsal çabalar olarak tanımlanmaktadır. ${ }^{1}$

Hemşirelik eğitimi öğrenci hemşirelerin bilgi, tutum ve becerilerini kullanmalarını sağlayan, onları hemşirelik mesleğini kazandırmayı hedefleyen, teorik ve klinik alt yapısı olan formal bir eğitim programıdır. Hemşirelik öğrencileri eğitim yaşantılarının ilk anlarından itibaren akademik performanslarını ve yaşam kalitelerini etkileyen stres unsurları ile karşı karşıya kalmaktadır. ${ }^{3,4}$ Yapılan çalışmalarda öğrencilerin yaşadıkları maddi sıkıntılar, ailevi sorunlar, cinsel sorunlar, depresyon, öğrencilerin akranları ile yaşadıkları sorunlar, akademik yük, akademik durumlarıyla ve klinik durumlarıyla ilgili 
bilgi ve beceri eksikliği, gelecekleri hakkındaki belirsizlik düşünceleri öğrencilerin stres yaşamalarına neden olabilmektedir. ${ }^{5-7}$

Son yillarda hemşirelik öğrencilerinin eğitimleri sürecinde diğer bölümlerde öğrenim gören öğrencilere göre stres yaşama ve stres unsurlariyla karşılaşma durumlarının daha fazla olması nedeniyle bu konu hakkında yapılan çalışmalara olan ilginin arttığı belirtilmektedir. ${ }^{8}$ Klinik anlamda geniş bir alanda görev yapan hemșirelik öğrencileri eğitimleri sırasında klinikte çalışan hemşirelerin deneyimlediklerine benzer stres yaşadıkları ve bunun yanında eğitimsel çalışmalar ve kişisel/sosyal nedenlerden kaynaklı stres yaşamaktadırlar. ${ }^{9}$ Deary 10 çalışmasında stresle baş etmede duygu odaklı baş etme ve kaçınan baş etme davranışları gösteren öğrenci hemşirelerin stres düzeylerinin daha yüksek olduğunu bildirmektedir. Sossah ve ark. ${ }^{11}$ yaptığ çalışmada öğrenci hemşirelerin klinik ortamda en fazla performans korkusu yaşadıkları ancak duygusal, manevi destek sistemlerini harekete geçirerek, okulda düzenlenen sosyal ve fiziksel aktivitelere katılarak stresle baş ettikleri belirtilmektedir. Yapılan çalışmalarda öğrenci hemşirelerin yaşadıkları stresin öğrencilerin akademik ilerlemelerini ve uyumlarını etkilediği bildirmektedir.,5,11

$\mathrm{Bu}$ araştırma öğrenci hemşirelerde stres yaratan durumlar ve baş etme yöntemlerini belirlemek amacıyla yapıldı.

\section{Araştırmanın Soruları}

- Öğrenci hemşirelerde stres yaratan durumlar nelerdir?

- Öğrenci hemşirelerin stresle baş etme yöntemleri nelerdir?

\section{Gereç ve yöntem}

tanımlayıcı tiptedir.

Araștırmanın tipi: $\mathrm{Bu}$ araştırma Araștırmanın evreni: Bir üniversitenin Sağlık Yüksekokulu Hemşirelik bölümünde 2014-2015 eğitim- öğretim yılında öğrenim gören öğrencilerin tamamı $(\mathrm{N}=531)$ bu araştırmanın evrenini oluşturmaktadır. Örneklem seçimine gidilmemiş, evrenin tamamına ulaşılması hedeflenmiștir. Gönüllülük ilkesi gereği araştırmaya katılmayı kabul eden 295 öğrenci ile çalışma gerçekleştirilmiştir. Ancak anket sorularını eksik dolduran 15 öğrencinin verileri çalışma kapsamı dışına alınmıştır. Böylece çalışma kapsamına alınanlar üzerinden evrenin \%53'üne ulaşılmıştır.

Verilerin Toplanmasl: Veriler "Öğrenci Hemșirelerde Stres Yaratan Durumlara İlişkin Bilgi Formu" ve "Stresle Başa Çılkma Ölçeği" kullanılarak 01.02.201410.06.2015 tarihleri arasında yüz yüze görüşülerek toplandı.

Öğrenci Hemșirelerde Stres Yaratan Durumlara İlişkin Bilgi Formu: Bilgi formu, ilgili literatür temel alınarak araştırmacılar tarafından geliştirildi. Hemşirelik öğrencilerinde stres yaratan durumları içeren ve 32 sorudan oluşan bu formda öğrencilerin sosyo-demografik özellikleri (yaş, eğitim durumu ve mesleği vb), öğrencilerin hemşirelik mesleğiyle ilgili düşünceleri, öğrencilerin klinik ve teorik eğitimler sırasında sosyal ve kişisel yaşamdaki stres kaynaklarına ilişkin sorular yer almaktadır. 3,4,12,13

Stresle Baş Etme Tarzları Ölçeği: Folkman ve Lazarus tarafından Başa Çıkma Yolları Envanteri olarak geliștirilen 4'lü likert tipi bir ölçektir. Ölçeğin 30 maddelik formunun Türkçe geçerlik ve güvenirlik çalışması Şahin ve Durak (1995) ${ }^{14}$ tarafından yapılmıştır. Ölçek kendine güvenli yaklaşım, çaresiz yaklaşım, boyun eğici yaklaşım, iyimser yaklaşım ve sosyal destek arama olmak üzere toplam 5 faktörden oluşmaktadır. Cronbach alfa iç tutarlılık katsayılarının ise, iyimser yaklașım için 0.49-0.68, kendine güvenli yaklaşım için 0.62-0.80, çaresiz yaklaşım için 0.64-0.73, boyun eğici yaklaşım için 0.47-0.72 ve sosyal destek arama faktörü için 0.45-0.47 arasında olduğu belirtilmiştir. Ölçeğin 8.,10.,14., 16., 20., 23., 26. maddeleri kendine güvenli yaklaşım; 2, 4., 6., 12., 18. maddeleri iyimser yaklaşım; 3., 7., 13., 15., 21., 24. 
maddeleri çaresiz yaklaşım; çaresiz yaklaşım; 5., 7., 13., 15., 21., 24. maddeleri boyun eğici yaklaşım; ve 1., 9., 29., 30. maddeleri ise sosyal destek arama maddeleridir. ${ }^{14}$

\section{Araştırmanın Etik Boyutu:} Araşturmanın her aşamasında etik ilkelere uyulmasına özen gösterilmiştir. Araştırmaya başlanmadan önce Mersin Üniversitesi Araştrrma Uygulama Merkezi Klinik Uygulamalar Etik Kurulu'ndan (25.09.2014 tarih ve 2014/216 sayll) etik kurul izni ve üniversitenin Sağlık Yüksekokulu Hemşirelik bölümünden kurum izni yazılı olarak alınmıştr. Öğrenci hemşirelere araşturmanın amacı ve yöntemi açıklanmıștır. Daha sonra yazılı ve sözlü onamları alınarak veriler toplanmıştur. Araştırmada kullanılan veri toplama formlarının uygulama süresi ortalama 20 dakika sürmüştür.

Verilerin Değerlendirilmesi: Elde edilen veriler Med Calc. paket programında değerlendirildi. Sürekli ölçümlere ait normallik kontrolleri Shapiro Wilk testi ile test edilmiş ve normal dağılım göstermediği tespit edilmiştir. Sosyo demografik özelliklerine göre bazı parametrelere göre alt ölçek puanları arasındaki farklılıklar için Mann Whitney U testi ve Kruskall Wallis testleri kullanılmıştır. İkili karşılaştırmalar için ise Mann Whitney U testi kullanılmıştır. Tanımlayıcı istatistikler olarak ortalama ve ortanca ve \%25-75 yüzdelikler kullanılmıştır. Ayrıca yaş değişkeni ile alt ölçek puanları arasındaki ilişki için Spearman korelasyon katsayısından yararlanılmıştır. Sonuçlar \%95'lik güven aralığında, anlamlılık $\mathrm{p} \leq 0.05$ düzeyinde değerlendirildi.

Araștırmanın

Sinirlılıkları:

Araştırmanın tek bir üniversitenin hemşirelik bölümünde uygulanmış olması sinırlılık olarak kabul edilmiştir.

\section{Bulgular}

$\mathrm{Bu}$ çalışmada öğrenci hemşirelerin \%58.3'ü 20 yaș ve üzerinde olup yaș ortalaması $21.0 \pm 2.0$ 'dir. Öğrenci hemşirelerin \%80.7'si kentsel bölgede yaşadığı, \%70.4'ünün gelir durumunun dengede olduğu, \%78.6'sı ise çekirdek aileye sahip olduğu belirlenmiştir. Öğrenci hemşirelerin \%74.3'ü hemşirelik bölümünü ilk beşinci sırada tercih ettiklerini, \%33.9'u 3 yıldır öğrenci olduğunu belirtmişlerdir. Öğrenci hemşirelerin hemşirelik mesleğini tercih etme nedenleri incelendiğinde öğrencilerin \%27.7'si mesleği sevdiği için, \%18'i ailesi istediği için, \%46.4'ü işsiz kalmamak için hemşirelik mesleğini tercih ettiğini bildirmiştir. Öğrencilerin \%57.1'i hemşire olmayı istediğini, $\% 25^{\prime} i$ ise bu konuda kararsız olduğunu belirtmiştir.

Öğrenci hemșirelerin klinik alandaki strese neden olan faktörler incelendiğinde; $\% 50.7$ 'si öğretim elemanlarının bakım planı konusundaki ısrarı/sıkıştırma davranışında bulunma, \%41.4'ü klinik hemşirelerinin öğrenciye saygılı olmayan tutumları, \%43.2'si hemşireler tarafından öğrencilere hemşirenin görev ve yetkileri dışındaki işleri yaptırmak istemesi, \%63.2'si hastaların öğrenci hemşireye güvenmemeleri, \%43.6'sı öğrencilerin klinik uygulamalarda hata yapma korkusu nedeniyle stres yaşadıklarını belirtmişlerdir (Tablo 1).

Öğrenci hemşirelerin \%48.2'si öğretim elemanının öğrenciyi motive edememesinden, \%44.6'sının sinav kaygısından, \%32.9'unun öğrencilerin diğer öğrencilerle yaşadıkları iletişim sorunlarından dolayı eğitim alanında stres yaşadıkları belirlenmiştir (Tablo 1).

Öğrencilerin sosyal yaşamları ile ilgili stres yaşadığı ve bunların \%26.8'inin üniversitede sosyal etkinliklerin olmaması, \%44.6'sının gruplaşmaların olması, $\% 22.5$ 'inin ise öğrenci yakınlarının hemşireliğe yönelik olumsuz ön yargısından dolayı stres yaşadıkları belirtilmektedir (Tablo 1).

Öğrenci hemşirelerin bireysel alanda stres yaşadıkları ve bunların \%31.1'inin kendini ifade edememe, \%30.4'ünün öfkeyi kontrol etmekte güçlük yaşama, \%42.5'inin aşırı duygusal olma, \%48.9'unun eğlence ile dersin zamanını ayarlayamama, \%30.4'ünün kendini yargılama ve suçlamadan kaynaklı stres yaşadıkları saptanmıştır (Tablo 1). 
Tablo 1. Öğrenci hemşirelerin klinik, eğitim, sosyal ve bireysel alanda deneyimlediği stresörlerin dağılımı

\begin{tabular}{|c|c|c|}
\hline Stresörler & $\mathrm{n}$ & $\%$ \\
\hline \multicolumn{3}{|l|}{ Klinik Alandaki Stresörler } \\
\hline Hastaların öğrenci hemşireye güvenmemeleri & 177 & 63.2 \\
\hline $\begin{array}{l}\text { Öğretim elemanlarının bakım planı konusundaki } \\
\text { ısrarı/sıkıştırması }\end{array}$ & 142 & 50.7 \\
\hline Öğrencilerin klinik uygulamalarda hata yapma korkusu & 122 & 43.6 \\
\hline Hemşirelik dışı isteklerde bulunma & 121 & 43.2 \\
\hline Hekimlerin öğrenciye saygılı olmayan tutumları & 120 & 42.9 \\
\hline Hemşirelerin öğrenciye saygılı olmayan tutumları & 129 & 41.4 \\
\hline \multicolumn{3}{|l|}{ Ĕğitim Alandaki Stresörler } \\
\hline Öğretim elemanının öğrenciyi motive edememesi & 135 & 48.2 \\
\hline Sınav kaygısı & 125 & 44.6 \\
\hline Öğrenciler arasındaki iletişim sorunları & 92 & 32.9 \\
\hline \multicolumn{3}{|l|}{$\underline{\text { Sosyal Alandaki Stresörler }}$} \\
\hline Gruplaşmaların olması & 125 & 44.6 \\
\hline Üniversitede sosyal etkinliklerin olmaması & 75 & 26.8 \\
\hline Yakınlarının hemşireliğe yönelik olumsuz ön yargısı & 63 & 22.5 \\
\hline \multicolumn{3}{|l|}{ Bireysel Alandaki Stresörler } \\
\hline Eğlence ile dersin zamanını ayarlayamama & 137 & 48.9 \\
\hline Aşırı duygusal olma & 119 & 42.5 \\
\hline Kendini ifade edememe & 87 & 31.1 \\
\hline Öfkeyi kontrol etmekte güçlük yaşama & 85 & 30.4 \\
\hline Kendini yargılama ve suçlama & 85 & 30.4 \\
\hline
\end{tabular}

Çalışmaya katılan öğrenci hemşirelerin "stresle başa çıkma tarzları ölçeği" alt ölçeklerinden aldığı puanlar sırasıyla; kendine güvenli yaklaşım $1.8 \pm 0.6$, çaresiz yaklaşım $1.2 \pm 0.6$, iyimser yaklaşım için $0.95 \pm 0.6$, boyun eğici yaklaşım $1.6 \pm 0.6$ ve sosyal destek arama yaklaşımı $1.8 \pm 0.6$ 'dır. öğrencilerin stresle başa çıkma

Mersin Univ Saglık Bilim Derg 2017;10(2) tarzları içerisinde en fazla kendine güvenli yaklaşım ve sosyal destek arama yöntemini kullandıkları saptanmıştır. En az kullandıkları yöntem ise boyun eğici yaklaşım'dır (Tablo 2).

Öğrenci hemşirelerin stresle başa çıkma ölçeğinin toplam ölçek ve alt ölçek boyutlarının puanları ile sosyo-demografik 
özelliklerine ilișkin bağımsız değișkenlerle ilişkisi incelendiğinde; stresle başa çıkma ölçeğinin alt boyutu olan çaresiz yaklaşım boyutu ile yaş grupları arasındaki farkın istatistiksel olarak anlamlı olduğu belirlenmiştir ( $\mathrm{p}=0.037)$. 20 yaşından küçük olan öğrenci hemşirelerin çaresiz yaklaşım alt ölçek puanlarının medyan değeri 21 yaş ve üstü olan öğrencilerden daha fazladır (Tablo 3).

Öğrenci hemşirelerin stresle başa
çıkma durumları ile cinsiyetleri
incelendiğinde; stresle başa çıkma ölçeğinin
boyun eğici yaklaşım, iyimser yaklaşım ve
sosyal destek arama yaklaşımı alt boyutları
ile öğrencilerin cinsiyetleri arasındaki farkın
istatistiksel olarak anlamlı olduğu
saptanmıstır $(\mathrm{p}=0.004, \mathrm{p}=0.042, \mathrm{p}=0.017)$.
Erkek öğrenci hemşirelerin boyun eğici

yaklaşım, iyimser yaklaşım alt ölçek puanlarının medyan değeri kadın öğrenci hemşirelerden daha fazladır. Kadın öğrenci hemşirelerin sosyal destek arama yaklaşımı alt ölçek puanının medyan değeri ise erkek öğrencilerden daha fazladır (Tablo 3).

Öğrenci hemşirelerin stresle başa çıkma durumları ile gelir gider durumları incelendiğinde, stresle başa çıkma ölçeğinin alt boyutu olan sosyal destek arama yaklaşımı boyutu ile öğrencilerin gelir durumu arasındaki farkın istatistiksel olarak anlamlı olduğu belirlenmiștir $(p=0.029)$. Geliri giderinden fazla olan öğrenci hemșirelerin sosyal destek arama yaklaşımı alt ölçek puanının medyan değeri gelir durumu az olan ve gelir durumu denk olan öğrenci hemşirelerin puanından daha düşüktür (Tablo 3).

Tablo 2. Öğrenci hemşirelerin stresle başa çıkma alt ölçeği puan ortalamaları $(n=280)$

\begin{tabular}{lcc}
\hline Stresle Başa Çıkma Ölçeği & $\bar{x} \pm S D$ & En Düşük-En Yüksek Değer \\
Boyun Eğici Yaklaşım & $0.95 \pm 0.6$ & $0-3$ \\
Sosyal Destek Arama & $1.8 \pm 0.6$ & $0-3$ \\
Kendine Güvenli Yaklaşım & $1.8 \pm 0.6$ & $0-3$ \\
İyimser Yaklaşım & $1.6 \pm 0.6$ & $0-3$ \\
Çaresiz Yaklaşım & $1.2 \pm 0.6$ & $0-3$ \\
\hline
\end{tabular}

Öğrenci hemşirelerin hemşirelik bölümünü tercih etme nedenleri ile stresle başa çıkma durumları incelendiğinde; stresle başa çlkma ölçeğinin alt boyutu olan çaresiz yaklaşımı boyutu ile hemşirelik bölümünü tercih etme nedenleri arasında istatistiksel olarak anlamlı bir fark olduğu belirlenmiştir ( $\mathrm{p}=0.047)$. Açıkta kalmamak için hemşirelik mesleğini tercih eden öğrencilerinin sosyal destek arama yaklaşımı alt ölçek puanının medyan değeri diğer nedenlerle (işsiz kalmamak, mesleği sevmek ve ailesi istediği için) hemşirelik mesleğini seçen öğrencilerden daha fazladır.Öğrenci hemşirelerin yaşadıkları yer ile stresle başa çıkma durumları incelendiğinde; stresle başa çıkma ölçeği'nin Mersin Univ Saglık Bilim Derg 2017;10(2) iyimser yaklaşım alt boyutu ile öğrencilerin yaşadıkları yer arasında istatistiksel olarak anlamlı bir fark olduğu belirlenmiștir $(\mathrm{p}=0.018)$. Aile/akraba, evde arkadaşı ile kalan öğrencilerinin iyimser yaklaşım alt ölçek puanının medyan değeri evde/yalnız ve yurtta kalan öğrencilerin puanından daha fazladır. Öğrenci hemşirelerin hemşire olmayı istemeleri ile stresle başa çıkma durumları incelendiğinde; stresle başa çlkma ölçeğinin kendine güvenli yaklaşım, çaresiz yaklaşım, boyun eğici yaklaşım, iyimser yaklaşım ve sosyal destek arama yaklaşımı ölçek alt boyutları ile hemşire olmayı isteme durumları arasında istatistiksel olarak anlamlı bir fark olduğu belirlenmiştir ( $p=0.010, p=0.036, p=0.024$, 
$\mathrm{p}=0.007, \mathrm{p}=0.018)$. Hemşire olmayı isteyen öğrencilerin kendine güvenli yaklaşım, iyimser yaklaşım, sosyal destek arama yaklaşımı alt ölçek puanının medyan değeri hemşire olmayı istemeyen ve kararsız olan öğrencilerden daha fazladır (Tablo 4).

Tablo 3. Öğrenci hemşirelerin sosyo-demografik özellikleri ile stresle başa çıkma ölçeği puan ortalamalarının dağılımı

\begin{tabular}{|c|c|c|c|c|c|c|c|}
\hline & Değişkenler & (n) & $\begin{array}{c}\text { Kendine } \\
\text { güvenli } \\
\text { yaklaşım } \\
\text { Medyan } \\
\text { [\% 25-75] }\end{array}$ & $\begin{array}{c}\text { Çaresiz } \\
\text { yaklaşım } \\
\text { Medyan } \\
\text { [\% 25-75] }\end{array}$ & $\begin{array}{l}\text { Boyun eğici } \\
\text { yaklaşım } \\
\text { Medyan } \\
\text { [\% 25-75] }\end{array}$ & $\begin{array}{c}\text { İyimser } \\
\text { yaklaşım } \\
\text { Medyan } \\
\text { [\% 25-75] }\end{array}$ & $\begin{array}{c}\text { Sosyal } \\
\text { destek } \\
\text { arama } \\
\text { yaklaşımı } \\
\text { Medyan } \\
\text { [\% 25-75] }\end{array}$ \\
\hline \multirow{5}{*}{$\underset{\pi}{\pi}$} & 20 Yaş ve altı & 117 & 1.86 & 1.38 & 1.00 & 1.60 & 1.75 \\
\hline & & & [1.43-2.29] & [0.88-1.75] & {$[0.50-1.33]$} & {$[1.20-2.00]$} & [1.25-2.25] \\
\hline & 21 Yaş ve üstü & 163 & 1.86 & 1.13 & 0.83 & 1.80 & 1.75 \\
\hline & & & [1.43-2.29] & {$[0.75-1.50]$} & [0.50-1.33] & {$[1.40-2.00]$} & {$[1.50-2.25]$} \\
\hline & & & $\mathrm{p}=0.580$ & $p=0.037$ & $\mathrm{p}=0.835$ & $\mathrm{p}=0.089$ & $\mathrm{p}=0.645$ \\
\hline \multirow{5}{*}{ 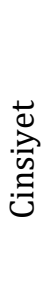 } & Kadın & 167 & 1.86 & 1.25 & 0.83 & 1.60 & 2 \\
\hline & & & [1.43-2.29] & {$[0.75-1.75]$} & [0.33-1.33] & {$[1.20-2.00]$} & {$[1.50-2.25]$} \\
\hline & Erkek & 113 & 1.86 & 1.12 & 1.00 & 1.80 & 1.75 \\
\hline & & & [1.43-2.29] & {$[0.75-1.56]$} & {$[0.67-1.42]$} & {$[1.40-2.20]$} & {$[1.25-2.00]$} \\
\hline & & & $\mathrm{p}=0.989$ & $\mathrm{p}=0.316$ & $p=0.004$ & $p=0.042$ & $p=0.017$ \\
\hline \multirow{5}{*}{ 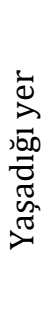 } & İl & 226 & 1.86 & 1.19 & 1.00 & 1.60 & 1.75 \\
\hline & & & [1.43-2.29] & [0.75-1.75] & {$[0.50-1.33]$} & {$[1.20-2.00]$} & {$[1.50-2.25]$} \\
\hline & Köy & 54 & 1.86 & 1.13 & 0.83 & 1.90 & 1.75 \\
\hline & & & {$[1.50-2.42]$} & [0.75-1.63] & {$[0.50-1.33]$} & {$[1.40-2.05]$} & {$[1.25-2.00]$} \\
\hline & & & $\mathrm{p}=0.942$ & $\mathrm{p}=0.425$ & $p=0.364$ & $\mathrm{p}=0.123$ & $p=0.287$ \\
\hline \multirow{5}{*}{$\begin{array}{l}\overline{\hat{Z}} \\
\frac{0}{\bar{z}}\end{array}$} & Geniş Aile & 60 & 29.0 & 1.25 & 0.83 & 1.80 & 1.75 \\
\hline & & & {$[6.0-36.0]$} & {$[0.75-1.62]$} & {$[0.50-1.33]$} & {$[1.40-2.20]$} & [1.31-2.18] \\
\hline & Çekirdek Aile & 220 & 1.85 & 1.12 & 1.00 & 1.60 & 1.75 \\
\hline & & & [1.43-2.29] & {$[0.75-1.63]$} & {$[0.50-1.33]$} & {$[1.20-2.00]$} & {$[1.50-2.25]$} \\
\hline & & & $\mathrm{p}=0.882$ & $\mathrm{p}=0.848$ & $\mathrm{p}=0.347$ & $\mathrm{p}=0.180$ & $\mathrm{p}=0.522$ \\
\hline \multirow{7}{*}{ 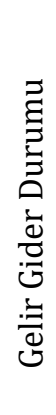 } & Gelir Giderden & 63 & 1.86 & 1.13 & 1.00 & 1.60 & 1.75 \\
\hline & & & {$[1.57-2.14]$} & [0.88-1.63] & {$[0.50-1.50]$} & {$[1.20-2.00]$} & {$[1.50-2.00]$} \\
\hline & Gider & 197 & 1.86 & 1.13 & 1.00 & 1.60 & 1.75 \\
\hline & Denk & & [1.36-2.29] & {$[0.75-1.75]$} & {$[0.50-1.33]$} & {$[1.20-2.00]$} & {$[1.50-2.25]$} \\
\hline & Gelir Giderden & 20 & 2.07 & 1.06 & 0.83 & 1.80 & 1.50 \\
\hline & & & [1.32-2.39] & [0.66-1.59] & [0.54-1.29] & {$[1.40-2.20]$} & [1.00-1.93] \\
\hline & & & $p=0.646$ & $\mathrm{p}=0.861$ & $\mathrm{p}=0.934$ & $p=0.666$ & $p=0.029$ \\
\hline
\end{tabular}


Tablo 4. Öğrenci hemşirelerin mesleki özellikleri ile stresle başa çıkma ölçeği puan ortalamalarının dağılımı

\begin{tabular}{|c|c|c|c|c|c|c|c|}
\hline & Değiş̧kenler & (n) & $\begin{array}{l}\text { Kendine } \\
\text { güvenli } \\
\text { yaklaşım } \\
\text { Medyan } \\
\text { [\% 25-75] }\end{array}$ & $\begin{array}{c}\text { Çaresiz } \\
\text { yaklaşım } \\
\text { Medyan } \\
\text { [\% 25-75] }\end{array}$ & $\begin{array}{c}\text { Boyun eğici } \\
\text { yaklassım } \\
\text { Medyan } \\
\text { [\% 25-75] }\end{array}$ & $\begin{array}{c}\text { İyimser } \\
\text { yaklaşım } \\
\text { Medyan } \\
\text { [\% 25-75] }\end{array}$ & $\begin{array}{c}\text { Sosyal } \\
\text { destek } \\
\text { arama } \\
\text { yaklaşımı } \\
\text { Medyan } \\
\text { [\% 25-75] }\end{array}$ \\
\hline \multirow{4}{*}{ 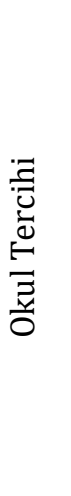 } & İlk 5 yll içinde & 208 & $\begin{array}{c}1.86 \\
{[1.57-2.29]}\end{array}$ & $\begin{array}{c}1.12 \\
{[0.75-1.63]}\end{array}$ & $\begin{array}{c}0.83 \\
{[0.50-1.33]}\end{array}$ & $\begin{array}{c}1.60 \\
{[1.20-2.00]}\end{array}$ & $\begin{array}{c}1.75 \\
{[1.50-2.25]}\end{array}$ \\
\hline & 6-10 yll içinde & 38 & $\begin{array}{c}1.86 \\
{[1.43-2.29]}\end{array}$ & $\begin{array}{c}1.13 \\
{[0.75-1.75]}\end{array}$ & $\begin{array}{c}0.92 \\
{[0.46-1.33]}\end{array}$ & $\begin{array}{c}1.60 \\
{[1.40-2.00]}\end{array}$ & $\begin{array}{c}1.75 \\
{[1.50-2.00]}\end{array}$ \\
\hline & 11 yıl ve üzeri & 34 & $\begin{array}{c}1.86 \\
{[1.29-2.29]}\end{array}$ & $\begin{array}{c}1.25 \\
{[0.84-1.66]}\end{array}$ & $\begin{array}{c}1.17 \\
{[0.67]}\end{array}$ & $\begin{array}{c}1.60 \\
{[1.15-2.00]}\end{array}$ & $\begin{array}{c}2.00 \\
{[1.50-2.25]}\end{array}$ \\
\hline & & & $\mathrm{p}=0.554$ & $\mathrm{p}=0.946$ & $p=0.227$ & $p=0.670$ & $\mathrm{p}=0.596$ \\
\hline \multirow{5}{*}{ 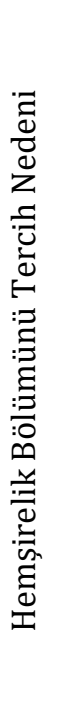 } & $\begin{array}{l}\text { Mesleği sevdiğim } \\
\text { için }\end{array}$ & 77 & $\begin{array}{c}2.00 \\
{[1.57-2.29]}\end{array}$ & $\begin{array}{c}1.00 \\
{[0.63-1.44]}\end{array}$ & $\begin{array}{c}0.83 \\
{[0.50-1.17]}\end{array}$ & $\begin{array}{c}1.80 \\
{[1.40-2.10}\end{array}$ & $\begin{array}{c}1.75 \\
{[1.50-2.25]}\end{array}$ \\
\hline & Ailem istediği için & 50 & $\begin{array}{c}1.86 \\
{[1.43-2.18]}\end{array}$ & $\begin{array}{c}1.38 \\
{[1.00-1.75]}\end{array}$ & $\begin{array}{c}1.00 \\
{[0.50-1.50]}\end{array}$ & $\begin{array}{c}1.50 \\
{[1.35-2.00]}\end{array}$ & $\begin{array}{c}1.75 \\
{[1.25-2.25]}\end{array}$ \\
\hline & $\begin{array}{l}\text { ÖSYM yerleştirme } \\
\text { sonucuna göre } \\
\text { herhangi bir } \\
\text { üniversiteye } \\
\text { yerleșebilmek için }\end{array}$ & 22 & $\begin{array}{c}2.07 \\
{[1.25-2.43]}\end{array}$ & $\begin{array}{c}1.38 \\
{[0.72-1.88]}\end{array}$ & $\begin{array}{c}1.00 \\
{[0.33-1.67]}\end{array}$ & $\begin{array}{c}1.80 \\
{[1.00-2.20]}\end{array}$ & $\begin{array}{c}2.00 \\
{[1.44-2.00]}\end{array}$ \\
\hline & $\begin{array}{l}\text { İşsiz kalmamak } \\
\text { için }\end{array}$ & 129 & $\begin{array}{c}1.86 \\
{[1.29-2.21]}\end{array}$ & $\begin{array}{c}1.13 \\
{[0.75-1.63]}\end{array}$ & $\begin{array}{c}0.83 \\
{[0.50-1.33]}\end{array}$ & $\begin{array}{c}1.60 \\
{[1.30-2.00]}\end{array}$ & $\begin{array}{c}1.75 \\
{[1.50-2.25]}\end{array}$ \\
\hline & & & $\mathrm{p}=0.451$ & $p=0.047$ & $p=0.332$ & $\mathrm{p}=0.332$ & $\mathrm{p}=0.577$ \\
\hline \multirow{4}{*}{ 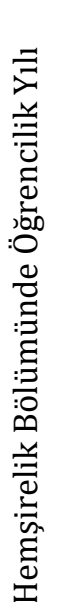 } & $1 \mathrm{yll}$ & 41 & $\begin{array}{c}1.86 \\
[1.36-2.21]]\end{array}$ & $\begin{array}{c}1.63 \\
{[0.94-1.88]}\end{array}$ & $\begin{array}{c}1.00 \\
{[0.58-1.58]}\end{array}$ & $\begin{array}{c}1.60 \\
{[1.10-2.10]}\end{array}$ & $\begin{array}{c}1.75 \\
{[1.25-2.13]}\end{array}$ \\
\hline & $2 \mathrm{yll}$ & 90 & $\begin{array}{c}1.86 \\
{[1.14-2.29]}\end{array}$ & $\begin{array}{c}1.13 \\
{[0.72-1.75]}\end{array}$ & $\begin{array}{c}0.92 \\
{[0.50-1.33]}\end{array}$ & $\begin{array}{c}1.60 \\
{[1.35-2.00]}\end{array}$ & $\begin{array}{c}1.75 \\
{[1.50-2.00]}\end{array}$ \\
\hline & 3 yil & 95 & $\begin{array}{c}2.00 \\
{[1.43-2.43]}\end{array}$ & $\begin{array}{c}1.13 \\
{[0.75-1.50]}\end{array}$ & $\begin{array}{c}1.00 \\
{[0.50-1.33]}\end{array}$ & $\begin{array}{c}1.80 \\
{[1.20-2.00]}\end{array}$ & $\begin{array}{c}1.75 \\
{[1.50-2.25]}\end{array}$ \\
\hline & 4 yıl ve üzeri & 54 & $\begin{array}{c}2.00 \\
{[1.57-2.14]} \\
p=0.274\end{array}$ & $\begin{array}{c}1.13 \\
{[0.75-1.50]} \\
p=0.170\end{array}$ & $\begin{array}{c}0.83 \\
{[0.46-1.33]} \\
p=0.627\end{array}$ & $\begin{array}{c}1.80 \\
{[1.40-2.05]} \\
p=0.505\end{array}$ & $\begin{array}{c}1.88 \\
{[1.50-2.06]} \\
p=0.588\end{array}$ \\
\hline
\end{tabular}


Tablo 4'ün devamı

\begin{tabular}{|c|c|c|c|c|c|c|c|}
\hline & Değişkenler & (n) & $\begin{array}{c}\text { Kendine } \\
\text { güvenli } \\
\text { yaklaşım } \\
\text { Medyan } \\
\text { [\% 25-75] }\end{array}$ & $\begin{array}{c}\text { Çaresiz } \\
\text { yaklaşım } \\
\text { Medyan } \\
\text { [\% 25-75] }\end{array}$ & $\begin{array}{l}\text { Boyun eğici } \\
\text { yaklaşım } \\
\text { Medyan } \\
{[\% 25-75]}\end{array}$ & $\begin{array}{c}\text { İyimser } \\
\text { yaklaşım } \\
\text { Medyan } \\
\text { [\% 25-75] }\end{array}$ & $\begin{array}{c}\text { Sosyal } \\
\text { destek } \\
\text { arama } \\
\text { yaklaşımı } \\
\text { Medyan } \\
\text { [\% 25-75] }\end{array}$ \\
\hline & Aile/akraba & 73 & $\begin{array}{c}2.14 \\
{[1.50-2.43]}\end{array}$ & $\begin{array}{c}1.25 \\
{[0.69-1.63]}\end{array}$ & $\begin{array}{c}1.00 \\
{[0.50-1.33]}\end{array}$ & $\begin{array}{c}1.80 \\
{[1.20-2.20]}\end{array}$ & $\begin{array}{c}2.00 \\
{[1.50-2.25]}\end{array}$ \\
\hline$\dot{\bar{d}}$ & Evde arkadaş & 66 & $\begin{array}{c}1.86 \\
{[1.29-2.29]}\end{array}$ & $\begin{array}{c}1.13 \\
{[0.75-1.53]}\end{array}$ & $\begin{array}{c}1.08 \\
{[0.50-1.50]}\end{array}$ & $\begin{array}{c}1.80 \\
{[1.40-2.05]}\end{array}$ & $\begin{array}{c}1.75 \\
{[1.25-2.00]}\end{array}$ \\
\hline 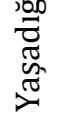 & Evde yalnız & 6 & $\begin{array}{c}1.64 \\
{[1.07-2.14]}\end{array}$ & $\begin{array}{c}1.19 \\
{[0.81-1.81]}\end{array}$ & $\begin{array}{c}1.17 \\
{[0.25-1.50]}\end{array}$ & $\begin{array}{c}1.30 \\
{[0.85-1.65]}\end{array}$ & $\begin{array}{c}1.63 \\
{[1.00-2.25]}\end{array}$ \\
\hline & Yurtta & 135 & $\begin{array}{c}1.86 \\
{[1.43-2.29]} \\
p=0.201\end{array}$ & $\begin{array}{c}1.13 \\
{[0.88-1.75]} \\
p=0.851\end{array}$ & $\begin{array}{c}0.83 \\
{[0.33-1.33]} \\
p=0.282\end{array}$ & $\begin{array}{c}1.60 \\
{[1.20-2.00]} \\
p=0.018\end{array}$ & $\begin{array}{c}1.75 \\
{[1.50-2.25]} \\
\mathrm{p}=0.352\end{array}$ \\
\hline$\underset{\Xi}{\tilde{\Xi}}$ & İstiyorum & 160 & $\begin{array}{c}2.00 \\
{[1.57-2.29]}\end{array}$ & $\begin{array}{c}1.13 \\
{[0.66-1.50]}\end{array}$ & $\begin{array}{c}0.83 \\
{[0.33-1.17]}\end{array}$ & $\begin{array}{c}1.80 \\
{[1.40-2.20]}\end{array}$ & $\begin{array}{c}2.00 \\
{[1.50-2.25]}\end{array}$ \\
\hline 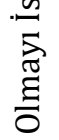 & İstemiyorum & 50 & $\begin{array}{c}1.71 \\
{[1.10-2.03]}\end{array}$ & $\begin{array}{c}1.25 \\
{[0.75-1.75]}\end{array}$ & $\begin{array}{c}1.00 \\
{[0.67-1.33]}\end{array}$ & $\begin{array}{c}1.40 \\
{[1.00-1.85]}\end{array}$ & $\begin{array}{c}1.63 \\
{[1.25-2.00]}\end{array}$ \\
\hline 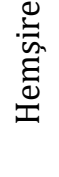 & Kararsızım & 70 & $\begin{array}{c}1.86 \\
{[1.25-2.14]} \\
p=0.010\end{array}$ & $\begin{array}{c}1.25 \\
{[0.88-1.88]} \\
p=0.036\end{array}$ & $\begin{array}{c}1.00 \\
{[0.50-1.50]} \\
p=0.024\end{array}$ & $\begin{array}{c}1.60 \\
{[1.20-2.00]} \\
p=0.007\end{array}$ & $\begin{array}{c}1.75 \\
{[1.25-2.00]} \\
p=0.018\end{array}$ \\
\hline
\end{tabular}

\section{Tartışma}

Çalışmaya katılan öğrenci hemşirelerin klinik, eğitim, sosyal ve bireysel alanda deneyimlediği strese neden olan faktörler incelendiğinde; öğretim elemanlarının bakım planı konusundaki ısrarı/sıkıştırması, hemşirelerin öğrenciye saygılı olmayan tutumları, hemşirelik dişı isteklerde bulunmaları, hastaların öğrenci hemşireye güvenmemeleri, öğrencilerin klinik uygulamalarda hata yapma korkusundan dolayı klinik alanda stres yaşadıkları belirlendi. Altıok ve ark. ${ }^{12}$ yaptığı çalıșmada da eğitici ile ilgili yaşadığı stres kaynakları temasıyla ilgili yargılayıcı tutumlar, bakım planı konusundaki

Mersin Univ Saglık Bilim Derg 2017;10(2) ısrarı/sıkıştırması, hekim ve öğrenci hekimlerin kendilerine gösterdikleri saygısızca tutum ve davranışlardan dolayı değersizlik yaşamalarından kaynaklı stres yaşadıkları bildirilmektedir. Pulido ve ark. ${ }^{15}$ yaptığı çalışmada öğrencilerin klinikte yanlış yapma korkusu, bilinmeyen durumlarla ile ilgili endișelere bağlı stres yaşadıkları belirtilmektedir. Singh ve ark. ${ }^{16}$ yaptığı çalışmada intörn öğrencilerin klinik ortamdaki stres seviyelerinin fazla olduğu öğrencilerin hastalardan, klinikteki beceri eksikliğinden kaynaklı olarak stres yaşadıkları belirtilmektedir. Evans ve ark. ${ }^{17}$ yaptığı çalışmada öğrenci hemşirelerin klinik ortamda hastalar ile yaşanan iletişim sorunları, klinik uygulamalara, iş yüküne ve 
çevreye bağlı stres yaşadıkları bildirilmektedir.

Çalışmamızda öğrenci hemşireler, öğretim elemanının öğrenciyi motive edememesinden, sınav kaygısından, öğrencilerin diğer öğrencilerle yaşadıkları iletişim sorunlarından dolayı eğitim alanında stres yaşadıklarını ifade etmektedir. Altıok ve ark.12 yaptığ çalışmada sınav kaygısı, ders motivasyonunun düşük olmasından öğrenciler arasındaki iletişim sorunlarından kaynaklı öğrenci hemşirelerin stres yaşadıkları bildirilmektedir. Pulido ve ark. ${ }^{15}$ yaptığı çalışmada öğrencilerin eğitim ile ilgili stres kaynakları arasında öğrenciler arasında yaşanan sorunlar, çalışma ile ilgili sorunlardan kaynaklı stres yaşadıkları belirtilmektedir. Güler ve ark. ${ }^{13}$ yaptığ çalışmada hemşirelik öğrencilerinin \%65.8'i eğitim ile ilgili stres yaşadığ yaşayan öğrencilerin \%3.8'inin öğretim elemanları ile ilgili stres yaşadıkları bildirilmektedir. Çalışma sonuçlarımız ulusal ve uluslararası yapılan çalışma sonuçları ile uyumludur.

$\mathrm{Bu}$ çalışmada öğrenci hemşirelerin üniversitede sosyal etkinliklerin olmamasından, gruplaşmaların olmasından, öğrenci hemşirenin yakınlarının hemşireliğe yönelik olumsuz ön yargısından dolayı stres yaşadıkları saptandı. Altıok ve ark. ${ }^{12}$ yaptığı çalışmada öğrenci hemşirenin yakınlarının hemşireliğe yönelik olumsuz ön yargısından, üniversitede sosyal etkinliklerin olmamasından, gruplaşmaların olmasından stres yaşadıkları bildirilmektedir.

$\mathrm{Bu}$ çalışmada öğrenci hemşirelerin kendini ifade edememe, öfkeyi kontrol etmekte güçlük yaşama, aşırı duygusal olma, eğlence ile dersin zamanını ayarlayamama, kendini yargllama ve suçlamadan kaynaklı stres yaşadıkları bulunmuştur. Altıok ve ark. ${ }^{12}$ yaptığ 1 çalışmada, kendini çok yargılama ve suçlama, eğlence ile dersin zamanını ayarlayamamadan dolayı stres yaşadıkları bildirilmektedir.

Çalışmaya katılan öğrenci hemşirelerin stresle başa çıkma tarzları içerisinde en fazla kendine güvenli yaklaşım ve sosyal destek arama yöntemini Mersin Univ Saglık Bilim Derg 2017;10(2) kullandıkları saptanmıştır. Temel ve ark. ${ }^{18}$ çalışmasında öğrenci hemşirelerin stresle baş etmede en çok kendine güvenli yaklaşım yöntemini kullandıkları bildirilmektedir. Güler ve ark. ${ }^{13}$ çalışmasında da öğrencilerin stresle başa çlkmada en fazla kendine güvenli yaklaşımı kullandıkları bildirilmektedir. Çalışmamız literatür ile benzerlik göstermekle birlikte öğrenci hemşirelerinin stresle başa çıkmada en fazla kendine güvenli yaklaşımı kullandıkları görülmektedir.

$\mathrm{Bu}$ çalışmada 20 yaşından küçük olan öğrenci hemşirelerin çaresiz yaklaşım puanlarının 21 yaş ve üstü olan öğrencilerden daha yüksek olduğu belirlenmiştir. Labrague ${ }^{8}$ yaptığı çalışmada yaşı küçük olan öğrenci hemşirelerin yaşı büyük olanlara göre stresle baş etmede daha çok duygusal odaklı tepkiler gösterdikleri ve bu durumunda yaşın artmasıyla öğrencilerin hem bilgi ve klinik deneyimlerinin artmasıyla hem de stresle karşılaştıklarında gerekli önleyici stratejileri ve problem çözme yollarını kazanmaları ile ilişkili olabileceği belirtilmektedir.

$\mathrm{Bu}$ çalışmada erkek öğrenci hemşirelerin boyun eğici yaklaşım, iyimser yaklaşım puanları kadın öğrenci hemşirelerden daha yüksek olduğu ve bununla birlikte kadın öğrenci hemşirelerin sosyal destek arama yaklaşımı puanının ise erkeklerden daha yüksek olduğu saptanmıştır. Güler ve ark.13 çalışmasında erkek öğrencilerin boyun eğici yaklaşım puanın kadınlardan daha yüksek olduğu belirtilmektedir. Bununla birlikte Ekinci ve ark. ${ }^{19}$ yaptığı çalışmada öğrenci hemşirelerin cinsiyetlerinin stresle başa çımma durumlarını etkilemediği ve bu durumun ise kız ve erkek öğrencilerinin herhangi bir stres durumunda benzer tepkiler göstermelerinden kaynaklı olabileceği bildirilmektedir. Karagözoğlu ve ark. $^{20}$ yaptığı çalışmada öğrenci hemşirelerin cinsiyetinin stres puanlarını etkilemediği belirtilmektedir.

Gelir durumu fazla olan öğrenci öğrencilerinin sosyal destek arama yaklaşımı alt ölçek puanının gelir durumu az olan ve gelir durumu dengede olanlardan 
daha düşük olduğu saptanmıștır. Labrague ${ }^{8}$ yaptığ algıladıkları stres düzeyinin ailelerinin gelir durumu ile bir ilişkisi olduğu ve ailesinin aylık geliri yüksek olan öğrenci hemşirelerin daha az stres yaşadıkları belirtilmektedir. Gelir durumu iyi olan öğrenci hemşirelerin stresli olduğu durumlarda yapabilecekleri aktivitelerin fazla olmasindan kaynaklanabileceği düşünülmektedir.

Üniversiteye yerleștirme sonucuna göre herhangi bir üniversiteye yerleşmiş olmak için hemşirelik mesleğini tercih eden öğrencilerinin sosyal destek arama yaklaşımı puanının diğer nedenlerle (işsiz kalmamak, mesleği sevmek ve ailenin istemesi) hemşirelik mesleğini seçen öğrencilerden daha yüksek olduğu belirlenmiştir. Arabacı ve ark. ${ }^{21}$ yaptığ çalışmada öğrenci hemşirelerin \%71.3'ü hemşirelik bölümünü isteyerek seçtikleri ve hemşirelik bölümünü isteyerek seçen öğrenci hemşirelerin klinik öncesinde, sirasinda ve sonrasinda daha az kaygı ve stres yaşadıkları belirtilmektedir. Hemşirelik mesleğini severek seçen öğrenci hemşirelerin klinikte daha az stres ve kaygı yaşamalarına bağlı olarak sosyal desteğe daha az gereksinim duymalarından kaynaklı olabileceği düşünülmektedir.

Hemşire olmayı isteyen öğrencilerin kendine güvenli yaklaşım, iyimser yaklaşım, sosyal destek arama yaklaşımı, çaresiz yaklaşım puanlarının hemşire olmayı istemeyen ve kararsız olan öğrencilerden daha yüksek olduğu belirlenmiştir. Temel ve ark. ${ }^{18}$ yaptığı çalışmada hemşirelik mesleğini isteyerek tercih eden öğrencilerin kendine güvenli ve iyimser yaklaşım puanlarının daha yüksek olduğu bildirilmektedir. $\mathrm{Bu}$ durumun öğrencilerin hemşirelik mesleğini severek ve isteyerek seçmelerinden kaynaklı olabileceği belirtilmektedir. Karagözoğlu ve ark.20 yaptığ 1 çalışmada öğrenci hemşirelerin büyük çoğunluğunun kendisini hemşirelik mesleğine ait hissettiği belirtilmektedir.

Mersin Univ Saglık Bilim Derg 2017;10(2)

\section{Sonuç}

Araştırma sonucunda öğrenci hemşirelerin eğitim ve klinik ortamda stres yaşadıkları belirlenmiştir. Öğrenci hemşirelerin yakınlarının hemşireliğe yönelik olumsuz ön yargısı, öğrenci hemşirenin kendisini ifade edememesi, öfkesini kontrol edememesi, öğrenci hemşirenin kendisini yargllaması ve suçlaması öğrenci hemşirelerin stres yaşamasına neden olmaktadır. Öğrenci hemşirelerin bu stresleri tanımaları ve stresle baş etme becerileri kazanmasında hemşire akademisyenlerin görev ve sorumluluklarının olması gerekmektedir. Hemşire akademisyenler öğrenci hemşireleri eğitim yaşantılarından itibaren güçlendirerek gerek öğrencinin gerekse mesleğin gelişimine katkı sunabilir.

\section{Kaynaklar}

1. Engin E. Anksiyete Bozuklukları. In: Çam O. Engin E. Ed: Ruh sağlığ ve hastalıkları hemşireliği bakım sanatı. 1. Baskl., İstanbul: İstanbul Medikal Yayıncilık, 2014:277-331.

2. Akman S. Stresin nedenleri ve açıklayıcı kuramlar. Türk Psikoloji Bülteni 2004;34-35,40-55.

3. Karaca A, Yıldırım N, Ankaralı H, Açıkgöz F, Akkuş D. hemşirelik öğrencileri için algılanan stres, biyopsiko-sosyal cevap ve stresle baş etme davranışları ölçeklerinin Türkçeye uyarlanması. Psikiyatri Hemşireliği Dergisi 2015;6(1):15-25.

4. Karaca A, Yıldırım N, Ankaralı H, Açıkgöz F, Akkuș D, Hemşirelik eğitimi stres ölçeği'nin Türkçeye uyarlanması. Hemşirelikte Araștırma Geliștirme Dergisi 2014;16(2):29-40.

5. Zyga S. Stress in nursing students. International Journal of Caring Sciences 2013;6(1):1-2.

6. Alzayyat A, Almaraira OA, Al-helih YM. Stress and coping among nursing students during their practical education in psychiatric settings: a literature review. Global Advanced Research Journal of Medicine and Medical Science 2015;4(5):240-247. 
7. Timmins F, Kaliszer M. Aspects of nurse education programmes that frequently cause stress to nursing students fact finding sample survey. Nurse Educ Today 2002;22:203-211.

8. Labrague L.J. Stress, stressors, and stress responses of student nurses in a government nursing school. Health Science Journal, 2013;7(4):424-435.

9. Pryjmachuk S, Richards DA. Mental health nursing students differ from other nursing students: some observations from a study on stress and coping. Int $J$ Ment Health Nurs 2007;16(6):390-402

10. Deary IJ, Watson R, Hogston RA. Longitudinal cohort study of burnout and attrition in nursing students. $J A d v$ Nurs.2003;43:71-8.

11. Sossah L, Asiedu Y. Stress management and resilıence in junıor and senıor nursing students in Ghana. European Journal of Research and Reflection in Educational Sciences 2015;3(2):46-53.

12. Altıok Ö.H, Üstün B. Hemşirelik öğrencilerinin stres kaynakları. Kuram ve Uygulamada Ĕgitim Bilimleri Dergisi 2013;13(2):747-766.

13. Güler Ö, Çınar S. Hemşirelik öğrencilerinin algıladıkları stresörler ve kullandıkları başetme yöntemlerinin belirlenmesi. Maltepe Üniversitesi Hemşirelik Bilim ve Sanatı Dergisi 2010; Sempozyum Özel Sayısi:253-261.

14. Şahin NH, Durak A. Stresle Başaçıkma tarzları ölçeği: üniversite öğrencileri için uyarlanması. Türk Psikoloji Dergisi 1995;10(34):56-73.
15. Pulido Martos M, Augusto Landa JM, Lopez Zafra E. Sources of stress in nursing students: a systematic review of quantitative studies. Int Nurs Rev 2011;59:15-25.

16. Singh C, Sharma S, Kumar Sharma R. Level of stress and coping strategies used by nursing interns. Nursing and Midwifery Research Journal 2011;7(4):152-160.

17. Evans W, Kelly B. Pre-registration diploma student nurse stress and coping measures. Nurse Education Today, 2004;24:473-482.

18. Temel E, Bahar A, Çuhudar D. Öğrenci hemșirelerin stresle bașetme tarzları ve depresyon düzeylerinin belirlenmesi. Fırat Sağlık Hizmetleri Dergisi 2007;2(5):107-118.

19. Ekinci M, Şahin Altun Ö, Can G. Hemşirelik öğrencilerinin stresle başa çıkma tarzları ve atılganlık düzeylerinin bazı değişkenler açısından incelenmesi. Psikiyatri Hemșireliği Dergisi 2013;4(2):67-74.

20. Karagözoğlu Ş, Özden D, Tok Yıldız F. Entegre program hemşirelik öğrencilerinin klinik stres düzeyi ve etkileyen faktörler. Anadolu Hemşirelik ve Sağlık Bilimleri Dergisi 2013;16(2):89-95.

21. Baysan Arabacı L, Akın Korhan E, Tokem Y, Torun R. Hemşirelik birinci sınıf öğrencilerinin ilk klinik deneyim öncesi-sırası ve sonrası anksiyete ve stres düzeyleri ve etkileyen faktörler. Hacettepe Üniversitesi Hemşirelik Fakültesi Dergisi 2015:1-16. 